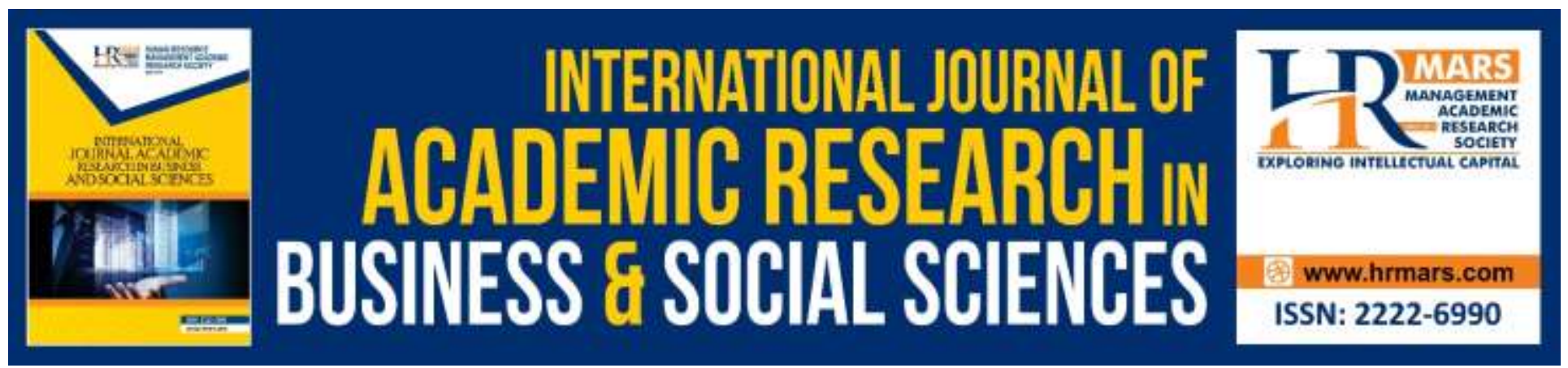

\title{
The Development and Evaluation of Malay Gamelan Module for Schools and Communities
}

Wong Huey Yi @ Colleen Wong, Christine Augustine, Zaharul Lailiddin bin Saidon, Suflan Faidzal Bin Arshad

To Link this Article: http://dx.doi.org/10.6007/IJARBSS/v9-i7/6090

DOI: $10.6007 /$ IJARBSS/v9-i7/6090

Received: 12 May 2019, Revised: 19 June 2019, Accepted: 1 July 2019

Published Online: 27 July 2019

In-Text Citation:(Wong, Augustine, Saidon, \& Arshad, 2019)

To Cite this Article: Wong, W. H. Y. @ C., Augustine, C., Saidon, Z. L. bin, \& Arshad, S. F. Bin. (2019). The Development and Evaluation of Malay Gamelan Module for Schools and Communities. International Journal of Academic Research in Business and Social Sciences, 9(7), 46-54.

\section{Copyright: (C) 2019 The Author(s)}

Published by Human Resource Management Academic Research Society (www.hrmars.com)

This article is published under the Creative Commons Attribution (CC BY 4.0) license. Anyone may reproduce, distribute, translate and create derivative works of this article (for both commercial and non-commercial purposes), subject to full attribution to the original publication and authors. The full terms of this license may be seen at: http://creativecommons.org/licences/by/4.0/legalcode

Vol. 9, No. 7, 2019, Pg. 46 - 54

Full Terms \& Conditions of access and use can be found at http://hrmars.com/index.php/pages/detail/publication-ethics 


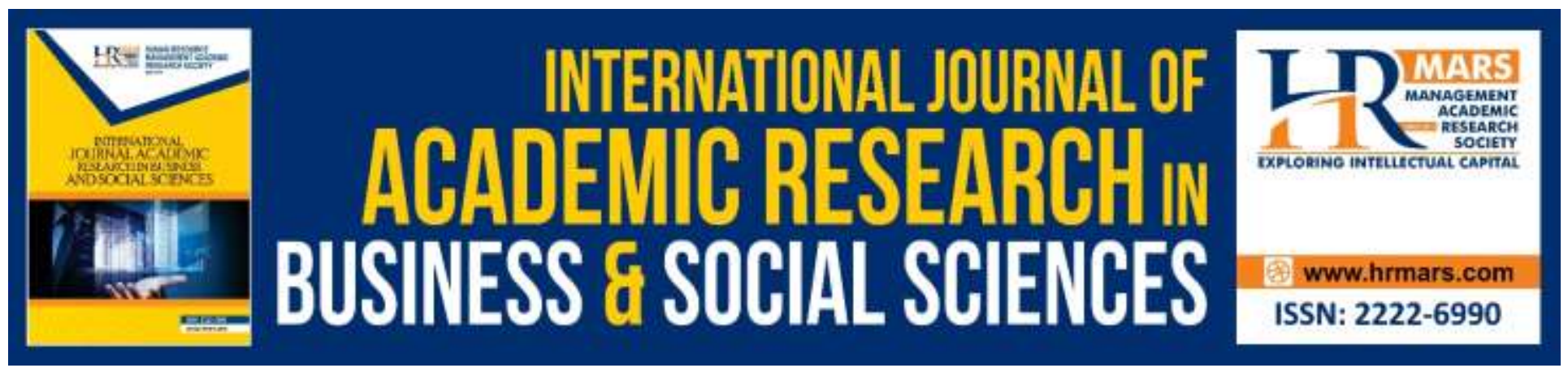

\title{
The Development and Evaluation of Malay Gamelan Module for Schools and Communities
}

\author{
Wong Huey Yi @ Colleen Wong, Christine Augustine, Zaharul \\ Lailiddin bin Saidon, Suflan Faidzal Bin Arshad \\ Universiti Pendidikan Sultan Idris, Malaysia
}

\begin{abstract}
It is crucial for every country to sustain and enrich their traditional music as very little written documentation is published. Many have mentioned that traditional music is taught orally through listening, observing, and playing. Skills of playing and knowledge are shared verbally within the community. The objectives of this research are focused on: 1) to identify patterns of playing in Malay gamelan; 2) to identify the techniques of teaching of Malay gamelan; and 3) to evaluate the selflearning module of Malay gamelan in teaching and learning. Observations conducted by the researchers indicate that Malay gamelan music has always been performed differently in terms of technical aspects in playing, especially during classes as well as in competitions. There is no standardized techniques and patterns in Malay gamelan playing. The reason for this because most traditional instruments in Malaysia are still taught orally although there is a guideline to be followed. In order to develop and evaluate the module, ASSURE model of teaching was used to help ensure the efficiency in designing this module. Respondents for this research consist of Malay gamelan experts. Four Malay Gamelan songs were identified; with specific patterns and techniques of playing and were transcribed to form a module with teaching units. The teaching units produced from the research hopes to educate Gamelan Melayu players.
\end{abstract}

Keywords: Malay Gamelan, Teaching and Learning, ASSURE Model, Module, Music

\section{Introduction}

In the $21^{\text {st }}$ century learning, the paradigm shift in education emphasizes on student centered learning rather than teacher centered (Donnelly \& Fitzmaurice, 2005). However, learning traditional instruments, which are considered informal learning, remains the same, as this has been the tradition in teaching and learning. Green (2009-10) indicated that informal music learning involves the integration of listening, performing, improvising and composing processes (rather than formal music education that tends to focus on just one of these activities at a time). This is also supported by Hardja 
(2010) and (Shahanum and Adam, 2016) who have mentioned that when learning traditional music, one does not rely much on notation but it is usually taught through listening, observing, and playing. Zaharul and Shahanum (2015) mentioned that in traditional learning method, aural tradition is highly used in the setting of its learning. Teachers within their students or via the community share skills of playing and knowledge verbally. Learning is transferred through the medium mentioned. Shahanum and Mohamad Adam also stated that in schools, the elements of authenticity were not given importance as students are taught traditional music based on the teacher's experience. Thus, according to Dunbar-Hall (2009) in Shahanum and Mohamad Adam, ethnopedagogy concept was introduced through the learning and teaching of music where it is perceived as culturally contextualized. Meaning that one needs to know the 'stories' behind Malay gamelan music as well as knowing the methodological approaches in music education. In developing a structured teaching of gamelan, Shahanum and Mohamad Adam emphasizes that students need to have a firm foundation to have a better understanding of the music. Students should grasp the playing techniques and the characteristic of the instrument. In a personal interview conducted with Pak Othman (20 ${ }^{\text {th }}$ September 2018); he mentions that students will play better when they know and understand what is delivered to them if they are equipped with prior knowledge in Malay gamelan. As the instruments consist mainly of metallaphone, the teaching units includes a section on knowledge of history and the details of each instrument. The authors also mention that it is important for students to describe specific instruments and learn traditional playing techniques and repertoires when they understand its characteristics.

Although there is no standardized method of teaching and learning of the Malay gamelan, Malaysian school syllabus introduces the learning of traditional instruments such as Kulintangan, 24 Season Drum and others under the topic Instrument Ensemble which includes the Malay Gamelan. Learning of selected ensemble are based on Dokumen Standard Kurikulum dan Pentaksiran (Curriculum and Assessment Standard) or known as DSKP (Kementerian Pendidikan Malaysia, 2015). DSKP is a component or guideline that consists of the standardization of content, pedagogy and assessment used in formal education. This guideline assists teachers in achieving their teaching and learning objective by being familiar with the right content. Based on the guidelines, the DSKP in music does not provide a suitable repertoires and steps of teaching and learning the Malay gamelan. Therefore, it is a challenge to the teacher to teach or to picture the students on learning the instrument. To ensure that the students-have a solid foundation of the Malay gamelan learning of which they should be able to understand the history as well as play the instrument; a specific guided teaching has to be created.

\section{Purpose of Study}

The purpose of this study is to develop a teaching and learning Gamelan Melayu ensemble units of module. The development of the module is crucial as it gives an organized or orderly teaching and learning method for any lesson provided by the teacher. Once students had already mastered the songs, they can play the songs without having to rely on the book. It can be also be recognized as a scaffolding in an educational learning process. These units of module will act as an evidence of teaching to the students. Subsequently it helps in establishing the students learning to be more 
structured. According to Masters, Thomson, Gillard, and Schleicher (2018) three basic of evidencebased teaching includes establishing the students' point of learning; 2) choose an appropriate teaching strategies as well as interventions; and 3) monitor student progress and evaluate teaching effectiveness. Thus, these units intend to expose learners with a guided teaching and learning module based on the researcher's findings.

\section{Problem Statement}

Teaching and learning traditional music has always been a hands-on approach where teachers do not have a proper-guided unit of lesson for their students. According to Grant (2017), teaching traditional instruments in Cambodia is described as an oral tradition but it is starting to emerge into notated learning. Grant also mentions that issues and challenges in the teaching and learning of traditional instruments have become more critical as youngsters have shown interest in modern music. This is because learning traditional instrument is difficult and needs time to be mastered based on the oral tradition approach.

\section{Objectives}

The objectives of this research are to:

1) identify patterns of playing in Malay gamelan;

2) identify the techniques of playing of Malay gamelan; and

3) evaluate the self-learning module of Malay gamelan in teaching and learning.

\section{Methodology}

A qualitative approach was used in this research. Recording of demonstration in gamelan playing and interviews with Malay gamelan experts were used to help in building and assessing the teaching units. Through interviews, a semi-structured interview was used to establish the research questions whereby these type of interviews are known as focused interview, whereby the interviewer is aware of the informer and at times questions will shift away from the main discussion (Jamshed, 2014). The researcher gained more information on the experiences and practices of the informant through questions that were prompt based on the ongoing interviews with the informants. Two informants identified by the researcher based on their skills as practitioners and academician. Interviews were recorded important notes were jotted to ensure information was not left out. According to Lebar (2015), it is important for the researcher to transcribe the notes after each interviews. Hence, the result gained through this approach were of techniques in the forms of gamelan's bunga or that of playing patterns in Malay gamelan were identified. This research uses purposive sampling which consists of Malay gamelan experts. Two experts identified by the researcher were based on their expertise in the industry and academic world.

\section{Subject}

The identified Malay gamelan experts who with more than ten years of experience have contributed by sharing of their experience, knowledge as well as technical aspects and patterns of playing the Malay gamelan. They facilitated on the module as soon as it was completed. Encik Osman Abdullah also known as Cikgu Osman is a famous gamelan facilitator and gamelan player with 30 years 
experiences in this field. He is the recipient of the Terengganu state government's special award (Anugerah Khas Majlis Aspresiasi Lambang Sari Gamelan Tradisional Melayu) for his achievement and contribution towards gamelan Melayu. Professor Madya Shahanum Mohd Shah is an academician who is also a practitioner in of gamelan Melayu. She has played with prominent contemporary gamelan group Rhythm in Bronze (RIB) as well as with the Gamelan Club. She also adjudicates many gamelan competitions in Malaysia.

\section{Research Instrument}

ASSURE model was used to develop a module for the teaching and learning of Malay gamelan. This model is an instructional system which incorporates a design process whereby the teacher builds a model as a form of support to their teaching and learning. According to Culatta (2013), the ASSURE model also integrates Robert Gagne's conditions of learning instruction in making sure the effectiveness of media instruction. The module acts as a self-learning module. According to Sidek and Jamaludin (2005) self-learning module is a form of teaching and learning which comprises of units of learning on the specific topic. It is systematically arranged for the learners to master the selected units.

\section{Procedures}

The process of the ASSURE model used in this study is as below:

A = Analyze Learners: The module was developed for students and communities who do not have any background of learning the Malay Gamelan. In this research, students were identified through random sampling.

S = State standards \& Objectives: This research has used the expertise of two Malay gamelan experts in looking up and analyzing the best materials for the module based on the interviews conducted with them. At the current state of learning Malay gamelan in school, there is no specific references for teaching and learning Malay gamelan. Based on the research conducted by the researcher, Dokumen Standard Kurikulum dan Pentaksiran (DSKP) by the Ministry of Education (MOE) is the only formal document used as a guideline in teaching Malay Gamelan ensemble.

$\mathbf{S}=$ Select Strategies, technology, media \& materials: Four songs from Malay gamelan repertoires were chosen after the observations, interviews and comparisons of materials were made. Gamelan storyline was arranged using media and technology to organize the book.

$\mathbf{U}=$ Utilize technology, media \& materials: The researcher recorded the playing (with permission) and transcribed into music numbers. The music was compiled and developed to a module of Malay Gamelan teaching and learning where units of teaching were introduced. Patterns of Malay Gamelan playing which were transcribed were attached to the books too.

$\mathbf{R}=$ Require learner's participation: Experts were given the teaching units to be proofread. 
INTERNATIONAL JOURNAL OF ACADEMIC RESEARCH IN BUSINESS AND SOCIAL SCIENCES

Vol. 9, No. 7, July, 2019, E-ISSN: 2222-6990 (C) 2019 HRMARS

$\mathbf{E}=$ Evaluate \& Revise: Amendments were made on each song after the evaluation.

\section{Findings}

Based on the interview conducted with the two Malay gamelan experts, teaching units of Malay gamelan learning was developed with the selection of four songs were identified for the beginners' level. It consists of 1) Perang Selinan; 2) Timang Burung; 3) Togok; and 4) Antawada. The songs selection is based on the level of difficulties. The selections were made based on the information given by the informants and was later defined by the researcher. Note that there are two lines shown in the extract. The top line played by left and vice versa but at times, it may change according to the song. The style of left and right playing with Keromong were obtained from Pak Othman; the researcher's informant.

In Perang Selinan, most of the notated notes are repetitions and do not have any difficult rhythm. Keromong has two patterns of quaver, which occur in every two bars before the range changes.

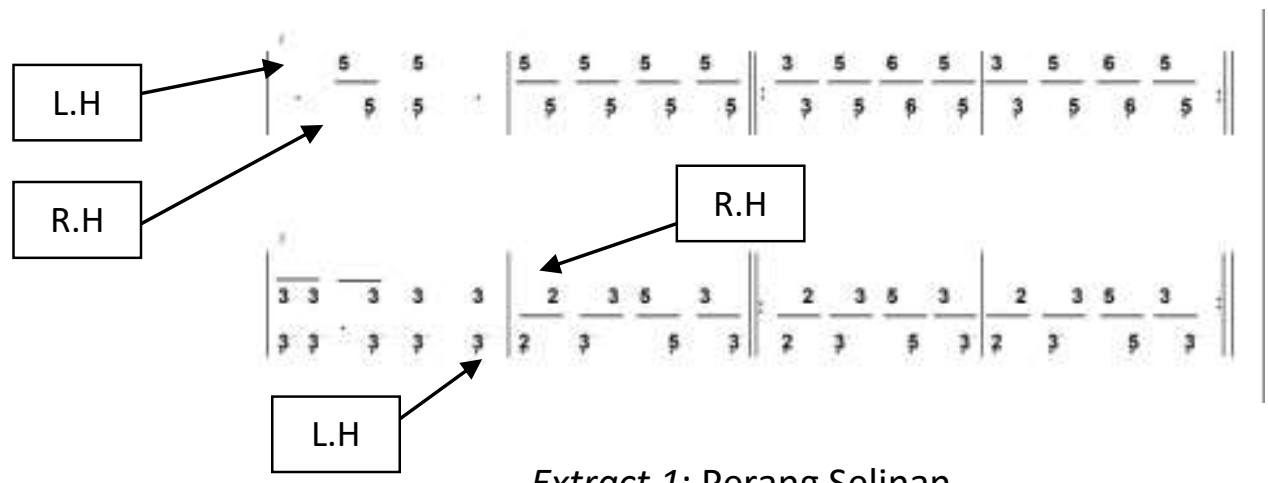

Extract 1: Perang Selinan

In Timang Burung some difficult rhythms are used especially at the line three and last line which also portray as the introduction of the song, which happens to be at the last four bars of the song.

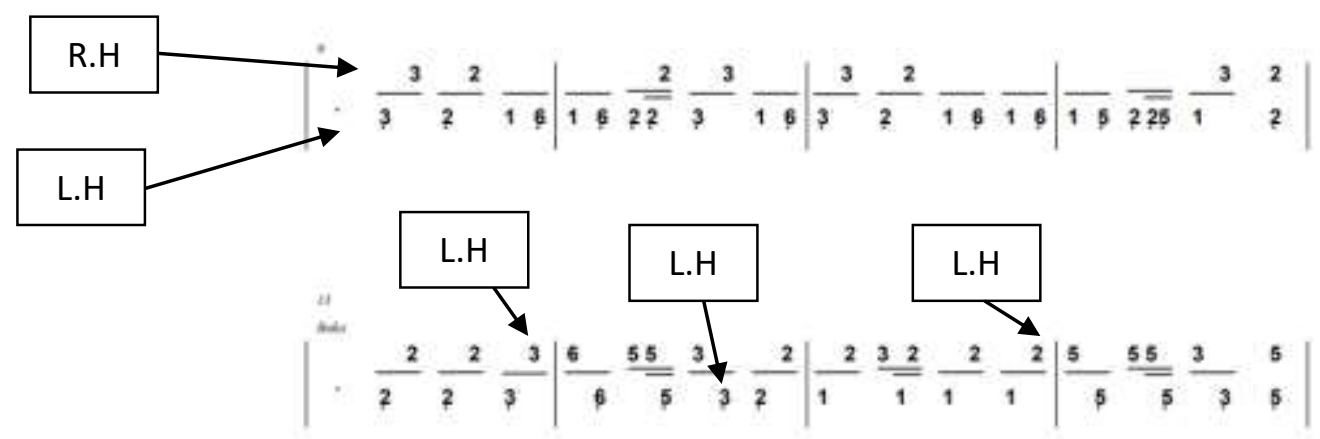

Extract 2: Timang Burung ( $3^{\text {rd }}$ \& last line) 
The third song known as Togok has patterns known as bunga are also used in playing this song. The movements of the hand are "busier" than the previous song.

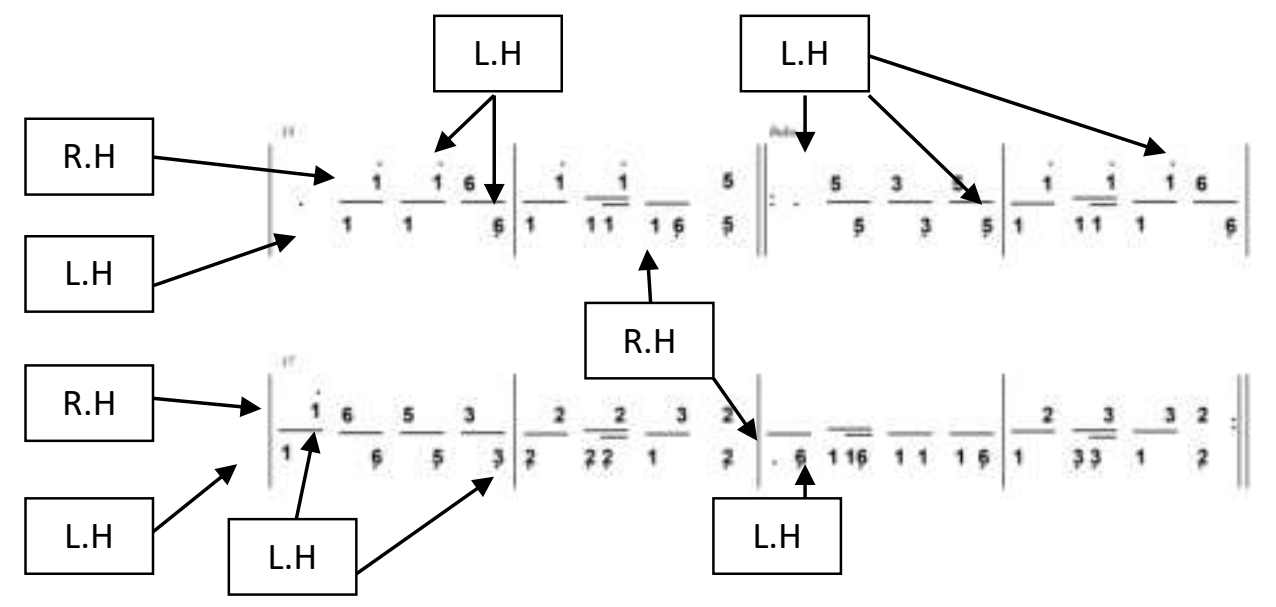

Extract 3: Togok ( $3^{\text {rd }}$ \& last line)

Antawada; the final song has a slightly different note value from the other three songs mentioned. The introduction or known as buka challenges the musician to play patterns or bunga differently. The tempo also are faster compared to the other songs.

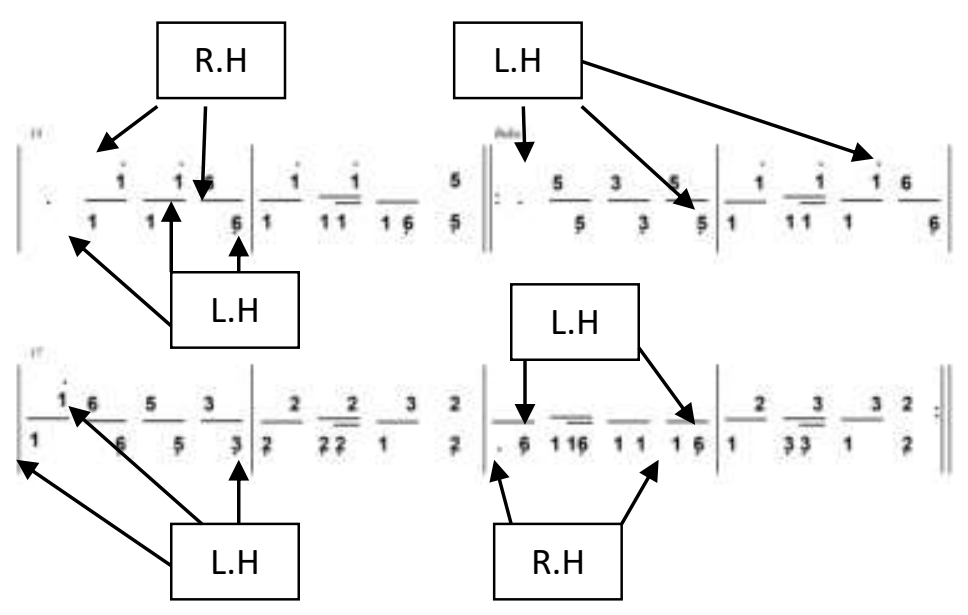

Extract 3: Antawada ( $3^{\text {rd }}$ \& last line)

The findings of the study based on the research questions are:

1) The patterns of playing the gamelan are identified with few steps in learning which consists of playing in octaves for the bonang player, and to a more advanced level which includes playing alternate notes and doubling. There rest of the instrument were played as it is written. 
2) The techniques of playing the gamelan are identified whereby the left hand or the right hand will change based on the keromong placement. In addition, the saron family is stressed in implementing a playing technique known as damping. There rest of the instrument will be played as it is written

3) The evaluation was conducted and amendments were made on each song based on the experts' comment and feedback.

\section{Conclusions}

Based on the research questions, the study has resulted in developing teaching units consisting of Malay gamelan teaching and learning repertoires, which provides references documented to new learners who are enthusiastic to learn in a systematic approach. Songs according to difficulty levels were displayed with simple bunga (patterns of playing) added in the teaching units based on the information gathered by the researcher. The style of playing on the keromong has also been written down in order for the player to play in an easier way to assist the position of the hands. This can be found in the extract shown in the writing. Furthermore, the steps and selection of songs were also been examined and validated through the informants (both practitioner and academician).

This research is expected to benefit students and teachers in schools as well as community music practitioners for them to learn to play the songs effortlessly as there are many styles of playing which has been carried out.

\section{Acknowledgment}

This research is funded by University Research Grant (2017-0150-107-01)/Geran Penyelidikan Universiti (GPU) with the total amount of RM6,820.00 from Research Management and Innovation Centre (RMIC) under Universiti Pendidikan Sultan Idris, Tanjong Malim, Malaysia. During research process, the author presented in International Music and Performing Arts Conference (IMPAC) 2018.

\section{References}

Black, J. (2003). Teaching gamelan in general music lessons in a secondary school: An investigation. Retrieved from http://www.music-research-inst.org/subs/im51/jblack.htm

Culatta, R. (2013). Assure. Retrieved from http://www.instructionaldesign.org/models/assure.html

Donnelly, R. \& Fitzmaurice, M. (2005). Emerging issues in the practice of university learning and teaching: Designing modules for learning. In O’Neill, G., Moore, S., \& McMullin, B. (Eds.). Aishe Readings (1). Retrieved from http://eprints.teachingandlearning.ie/2917/1/ McCarthy\%20and\%20Higgs\%202005.pdf

Gilbert, A. D. (2016). The framework for 21st century learning: A first-rate foundation for music education assessment and teacher evaluation. Arts Education Policy Review, 117(1), 13-18. doi: 10.1080/10632913.2014.966285

Grant, C. (2017). Learning and teaching traditional music in Cambodia: Challenges and incentives. International Journal of Music Education, 35(1), p.g. 5-16. doi: 10.1177/0255761415619394

Green, L. (2009-10). Music, informal learning and the schools. Journal of the Society for Musicology in Ireland, 5. p. 109. 
Kementerian Pendidikan Malaysia. (2015). Pendidikan Muzik: Dokumen Standard Kurikulum dan Pentaksiran, Tingkatan1. Retrievedhttps://cms.mrsm.edu.my/cms/documentstorage/ com.tms.cms.document.Document_d7da9eb3-ac12c870-38675e41fc664bf1/006\%20 DSKP\%20Pendidikan\%20Muzik\%20KSSM\%20Tingkatan\%201.pdf

Masters, G., Thomson, S., Gillard, J., \& Schleicher, A. (2018). Teacher: The role of evidence in teaching and learning. Retrieved from https://www.teachermagazine.com.au/columnists/ geoff-masters/the-role-of-evidence-in-teaching-and-learning

Shah, S. M., \& Masumi, M. A (2016). Teaching traditional music in Malaysian schools: Considering the cultural context. International Journal of Learning and Teaching, 8(1), 69-76.

Shazia Jamshed. (2014). Qualitative research method-interviewing and observation. Journal of Basic and Clinical Pharmacy, 5(4), 88. doi: 10.4103/0976-0105.141942

Noah, S. M., \& Ahmad, J. (2005). Pembinaan modul: Bagaimana membina modul latihan dan modul akademik. Serdang: Penerbit Universiti Putra Malaysia.

Saidon, L. Z., \& Nor, S. M. (2015). Penilaian dan pensijilan bagi muzik

tradisional Malaysia berdasarkan model peperiksaan muzik bergred antarabangsa. Malaysian Music Journal 4(1), m.s.47-66. 